九州大学学術情報リポジトリ

Kyushu University Institutional Repository

\title{
Biodegradation of Cinnamates by White-Rot Fungus, Phlebia Radiata
}

Cho, Nam-Seok

Wood and Paper Science, Chungbuk National University

Rogalski, Jerzy

Department of Biochemistry, Maria Curie-Sklodowska University

Deptula, Tomasz

Department of Biochemistry, Maria Curie-Sklodowska University

Staszczak, Magdalena

Department of Biochemistry, Maria Curie-Sklodowska University

他

https://doi.org/10.5109/16105

出版情報：九州大学大学院農学研究院紀要. 54 (2)，pp. 285-291，2009-10-29. Faculty of Agriculture, Kyushu University

バージョン :

権利関係 : 


\title{
Biodegradation of Cinnamates by White-Rot Fungus, Phlebia Radiata
}

\author{
Nam-Seok CHO ${ }^{1}$, Jerzy ROGALSKI ${ }^{2}$, Tomasz DEPTUŁA ${ }^{2}$, Magdalena STASZCZAK ${ }^{2}$, \\ Grzegorz JANUSZ ${ }^{2}$, Hee-Yeon $\mathbf{C H O}^{3}$, Soo-Jeong SHIN $^{1}$ \\ and Shoji OHGA*
}

\author{
Laboratory of Forest Resources Management, Division of Forest Ecosphere Management, \\ Department of Forest and Forest Products Sciences, Kyushu University, \\ Sasaguri, Fukuoka 811-2415, Japan \\ (Received May 18, 2009 and accepted July 13, 2009)
}

\begin{abstract}
This study was attempted to elucidate the biochemical mechanism of cinnamate compounds labeled specifically ${ }^{14} \mathrm{C}$ in the different position. The pathways for cinnamate metabolism have been studied in detail for the white-rot fungus Phlebia radiate and the reaction sequence has been proposed. ${ }^{14} \mathrm{CO}_{2}$ release from carboxyl labeled cinnamate reached the maximum after $24 \mathrm{hrs}$ on the medium with wheat straw and after 48 hrs on the media with glucose and spruce wood. In the case of the medium with cellulose the release of carbon dioxide increases linearility up to the $8^{\text {th }}$ day of the cultivation. The evolution of carbon dioxide from aliphatic chain cleavage cinnamate showed very similar trend which demonstrated simultaneous process with the decarboxylation ones on all tested media. About 30\% of carbon dioxide evolved from carboxyl-labeled cinnamate. The radioactivity in the mycelium was also above $10 \%$ in all cases and can be read as partially degraded or metabolized to the other components. The cellulose slightly repressed the decarboxylation of cinnamate in opposition to wheat straw and spruce wood, which doubled degradation. The maximum rate of decarboxylation was ca. $1.2 \%$ of the applied activity evolved as ${ }^{14} \mathrm{CO}_{2}$ per hour. According to identified metabolites, at first the substrates after decarboxylation, and aliphatic chain cleavage were demethylated in the position 4 following the demethylation in the position 3 and finally aromatic ring cleavage were observed in air and oxygen aeration on the media with glucose, cellulose, wheat straw and spruce wood.
\end{abstract}

\section{INTRODUCTION}

The final step in the formation of lignin in the cell walls of vascular plants is a dehydrogenative polymerization of the monomeric precursors, $p$-coumaryl-, coniferyl- and sinapyl-alcohols (Freudenberg, 1965). The reaction is initiated by an oxidative enzyme (peroxidase or laccase), but the polymerization itself is currently viewed as being a process without enzymatic control over the distribution of structural units (Monties, 1989). The composition of the monomeric precursors of lignins depends on guaiacyl, guaiacyl-syringyl or guaiacylsyringyl-p-hydroxyphenyl lignins depending on their origin: gymnosperms, angiosperms except grasses (Lewis and Yamamoto, 1990). Variations in the monomer composition of lignins also depend on the growth conditions, stresses and genetic variations (Monties, 1989). The sources of lignocellulose that occur in various forms in nature are so vast that they can only be compared to those of water (Bellamy, 1974). Lignocellulose is a compact, in part crystalline, complex. Polysaccharide components form microfibers and are densely packed in layers of lignin which protects them against the activity of hydrolytic enzymes and other external factors and which also serves as a stabilizer of the complex structure (Fengel, 1971). This structure endows plants with the

\footnotetext{
Wood and Paper Science, Chungbuk National University, Cheongju 361-763, Korea

2 Department of Biochemistry, Maria Curie-Sklodowska University, 20-031 Lublin, Poland

Molecular Microbiology and Immunology, University of Southern California, Los Angeles, CA 90089, USA

* Corresponding author (E-mail: ohga@forest.kyushu-u.ac.jp)
}

necessary stiffness and performs in plants the function similar to a block of concrete with metal rods inside; its durability comes from the compact structure. There exists an analogy between metal rods inside prefabricated elements and cellulose fibres in lignin (Leonowicz et al., 1997).

The biodegradation of the lignocellulose constituents, cellulose, hemicelluloses and lignin, is achieved by enzymatic activities. The conversion of cellulose and hemicelluloses into simple sugars has been studied for a long time. A large number of micro-organisms (bacteria, fungi and protozoas) make use of a whole string of hydrolases which are able to produce large quantities of mono- and di-saccharides from all polysaccharide components in lignocellulose. The degradation, however, is effected by the occurrence of polysaccharides in a complex with lignin because the latter forms a barrier against the microbial attack by hydrolytic enzymes. The lignin barrier also complicates cellulose production in the pulp and paper industry. For these ecological, economic and other reasons, research into the biotransformation of lignin has been carried out for decades (Leonowicz et al., 1987; Eriksson et al., 1990).

Wood-rotting basidiomycetes penetrate wood tissues in order to come into contact with the easily assimilable carbohydrate constituents of the lignocellulosic complex. The white-rot group of these fungi, which has a versatile machinery of enzymes co-operating with certain secondary metabolites of fungi, is capable of attacking the lignin barrier efficiently. These fungi use a multienzyme system including the so-called "feed-back" type enzymes to transform and degrade all structural elements of the lignocellulosic complex (polysaccharides 
and lignin). The currently known enzymes of white-rot fungi involved in wood degradation can be divided into three groups. The first can attack the wood constituents or their primary degradation products directly; this group includes the cellulase and hemicellulase complexes, laccase, different peroxidases, protocatechuate-3,4-dioxygenase, etc. The second group of enzymes, comprising among others arylalcohol oxidase and glyoxal oxidase, co-operates with the first group by providing $\mathrm{H}_{2} \mathrm{O}_{2}$ for the peroxidases, but these enzymes do not attack wood components directly. The third enzyme group represented by glucose oxidase and cellobiose:quinone oxidoreductase (cellobiose dehydrogenase) includes feedback type enzymes which play a key role in joining the metabolic chains during the biotransformation of highmolecular mass wood constituents. All these enzymes, including laccase, can act separately or in co-operation (Leonowicz et al., 1999).

The lignin-degrading Basidiomycete Phanerochaete chrysosporium synthesizes de novo from glucose via phenylalanine: veratryl alcohol, ferulic acid, 3,4-dimethoxycinnamic alcohol, and veratryl glycerol (Shimada et al., 1981; Shimada et al., 1989). The similar results were obtained in our previous paper for Phlebia radiata growing on the ADMS medium (Rogalski et al., 1996). Additionally, after the induction by ferulate and vanillate components synthesis de`novo was initially stopped (only the methylation process of vanillate and ferulate components were observed). Subsequently, between the $6^{\text {th }}$ and $8^{\text {th }}$ day of the growth the maximum of the synthesis de novo was observed (Rogalski et al., 1992). However, in addition to oxidized products considerable amounts of coniferyl alcohol accumulated when the Trametes species was grown in the presence of ferulic acid. Similarly, when using anisic acid as a substrate, a rapid transformation of this acid into aldehyde and alcohole by certain wood destroying fungi was observed, with the preference to oxidative conversion as found by Shimazono et al. (1978). Phenolic acids can stimulate the production of cellulolytic enzymes such as hemicellulolytic ones (Rogalski et al., 1992; Longa, 1996).

The production of lignolytic enzymes can be induced by certain low molecular weight aromatic compounds, toxic aromatic compounds and lignin preparations (Rogalski et al., 1991; Rogalski et al., 1992). Having too big molecular weight, these enzymes cannot penetrate the undegraded plant cell wall (Evans et al., 1991; Fluornoy et al., 1991; Evans et al., 1994). On the other hand, there have been studied presenting the evidence that some of these enzymes (e.g. laccase) are able to bleach hardwood pulp by depolymerizing and solubilizing lignin in the presence of so-called mediator compounds (Bourbonnais and Paice, 1992; Bourbonnais et al., 1995; Call, 1994; Call and Mucke, 1997; Majcherczyk et al.,1999). Consequently, it has been suggested that many low-molecular weight compounds permeate wood cell walls and initiate decay. Examples of such substances include veratryl alcohol, oxalate, 3-hydroxyanthranilic acid, and Gt-chelators. They are produced as a result of fungal metabolism and their secretion enables fungi to colonize and degrade the wood cell wall structure more effectively than other organisms. The synthesis of veratryl alcohol was first observed in Phanerochaete chrysosporium (Lundquist and Kirk, 1978); oxalate and other organic acids were already found in culture liquids of a number of wood-rotting fungi in 1965, for example Armillaria mellea, Fomes annosus, and Pleurotus ostreatus (Takao, 1965). Later, their secretion was also shown for solid-state cultures (Galkin et al., 1998; Hofrichter et al., 1999). 3-Hydroxyanthranilic acid was isolated and identified from Pycnoporus cinnabarinus (Eggert et al., 1996 and Eggert et al., 1997), and a special phenolate derivative, the so-called Gt-chelator (molecular mass $<1 \mathrm{kDa}$ ), was isolated from the brownrot fungus Gleophyllum trabeum (Goodell et al., 1996). Pseudomonas acidovorans, Bacillus subtilis and Rhodotorula rubra metabolize ferulic acid to vanillin, vanillic acid and protocatechuic acids (Toms and Wood, 1970; Gurujeyalakshimi and Madahevan, 1987; Huang et al., 1993). Some microorganisms further convert vanillic acid to guaiacol and methoxyhydroquinone (Crawford and Olson, 1978; Buswell et al., 1979). Ferulic acid is also converted to methoxy derivatives of acetophenone (Jurkova and Wurst, 1993) to 4-hydroxy-3-methoxystyrene (Huang et al., 1993), to caffeic- and 3-methoxy-4hydroxyphenylpropionic- acid by many microorganisms (Bache and Pfennig, 1981; Chesson et al., 1982; GrbicGalic, 1985). A little work has been done to elucidate the biochemical mechanism by which substituted cinnamates are converted to any of these aromatic compounds. In the present paper the metabolism of cinnamic components labeled specifically ${ }^{14} \mathrm{C}$ in the different position has been reported.

\section{MATERIALS AND METHODS}

\section{Organism and cultural condition}

Phlebia radiata Fr no 79 [ATCC 64658] was isolated at the Department of Microbiology, University of Helsinki (Hatakka and Uusi-Rauva, 1983) and was maintained on $2 \%(\mathrm{w} / \mathrm{v})$ malt agar slants. The preparation of inoculum was performed according to (Hatakka and UusiRauva, 1983). After the 6 -day growth in $28^{\circ} \mathrm{C}$ the mycelial mats were collected and homogenized in a Warning Blender. After the inoculation with $4 \%(\mathrm{v} / \mathrm{v})$ of the homogenate, $100 \mathrm{ml}$ conical flasks, each containing $10 \mathrm{ml}$ of ADMS-LN medium with 1\% glucose, 1\% cellulose, $1 \%$ wheat straw or $1 \%$ spruce wood as a carbon source, were incubated stationary at $28^{\circ} \mathrm{C}$. On the $3^{\text {rd }}$ day of growth cinnamic acid in the concentration of $1 \mathrm{mM}$ and about $1 \mathrm{kBq}$ of cinnamate isotopes specifically labeled on different positions were added to each inoculated flask. The flasks were then fitted with polypropylene stoppers (Kartel, Italy). Radiorespirometric methods to collect evolving ${ }^{14} \mathrm{CO}_{2}$ and the assay of radioactivity were used according to Hatakka and Uusi-Rauva (1983). Sterile synthetic air (20\% oxygen) or pure oxygen were used for aeration and ${ }^{14} \mathrm{CO}_{2}$ collection purposes. Culture flasks (10 ml sample) were taken in duplicate every $24 \mathrm{~h}$. Cultures were filtrated by Whatman No. 4 filter paper on 
a glass filter (Schott No. 4, Duran, FRG), and the filter paper plus mycelium was combusted as described by (Hatakka and Uusi-Rauva, 1983) to determine the mycelial ${ }^{14} \mathrm{C}$-activity. The radioactivity was counted in liquid scintillation counters (LKB-Willa Oy, Finland and Beckman type LS 5000TD, Germany).

\section{Chemicals}

Carboxyl-labeled p-hydroxy cinnamic acid $\left({ }^{14} \mathrm{COOH}\right.$ $\left(\mathrm{C}_{1}\right)$-cinnamate; $\left.35.7 \times 10^{3} \mathrm{~Bq} / \mathrm{mg}\right)$, methoxyl-labeled dimethoxy cinnamate in position -3 and $4\left(3-\mathrm{O}^{14} \mathrm{CH}_{3}-\right.$ cinnamate; $\quad 27.3 \times 10^{3} \mathrm{~Bq} / \mathrm{mg} ; \quad 4-\mathrm{O}^{14} \mathrm{CH}_{3}$-cinnamate; $34.3 \times 10^{3} \mathrm{~Bq} / \mathrm{mg}$ ), and $p$-hydroxycinnamate labeled in aliphatic chain in $\mathrm{C}_{3}$ position $\left(\mathrm{C}_{3}\right.$-cinnamate; $36.8 \times 10^{3} \mathrm{~Bq} /$ mg) were kindly supplied by Dr. Konrad Haider and Prof. Jerzy Trojanowski, Inst. für Pflanzenernchrung und Bodenkunde, Bundesforschungsanstalt für Landwirtschaft, Braunschweig, Germany.

\section{HPLC analysis}

HPLC was carried out using a Shimadzu liquid chromatograph equipped with high pressure pumps LC-9A, a gradient system, and diode array UV-visible spectrum detector SPD-M6A connected to an IBM Pentium II data system. The reversed phase column was a Novopack- $\mathrm{C}_{18}$ column (3.9 mm $\times 150 \mathrm{~mm}$; Waters Assoc. Inc.). All analyses were run with gradient elution by using HPLC gra- dient grade acetonitrile (Merck) and $1 \mathrm{mM} \mathrm{H}_{3} \mathrm{PO}_{4}(\mathrm{pH}$ 3.2). The gradient was partially linear, with acetonitrile $(\mathrm{v} / \mathrm{v})$ increase as follows: $11 \%$ (0 min); $25 \%$ (5 min); $25 \%$ (6 min); 40\% (8 min); 60\% (11 min); and 60\% (15 min) as in Lundell et al. (1990).

\section{RESULTS AND DISCUSSION}

The dynamics of ${ }^{14} \mathrm{CO}_{2}$ release by $P$. radiata was measured in a standing culture containing as the sole carbon source: a) unlabeled $p$-hydroxycinnamic acid and separately, carboxyl-, or $\mathrm{C}_{3}$-labeled cinnamate; B) unlabelled dimethoxycinnamic acid and separately, 3-methoxy- or 4-methoxy cinnamate.

Fig. 1A demonstrates that ${ }^{14} \mathrm{CO}_{2}$ release from carboxyl labeled cinnamate reached the maximum after 24 hrs on the medium with wheat straw and after 48 hrs on the media with glucose and spruce wood. In the case of the medium with cellulose the release of carbon dioxide increases linearility up to the $8^{\text {th }}$ day of the cultivation. The evolution of carbon dioxide from aliphatic chain cleavage cinnamate (Fig. 1B) showed very similar trend which demonstrated simultaneous process with the decarboxylation ones on all tested media. The processes of the demethylation of 4-methoxy group (Fig. 1D) and demethylation of 3-methoxy group (Fig. 1C) were next observed in all cases. Among these processes only
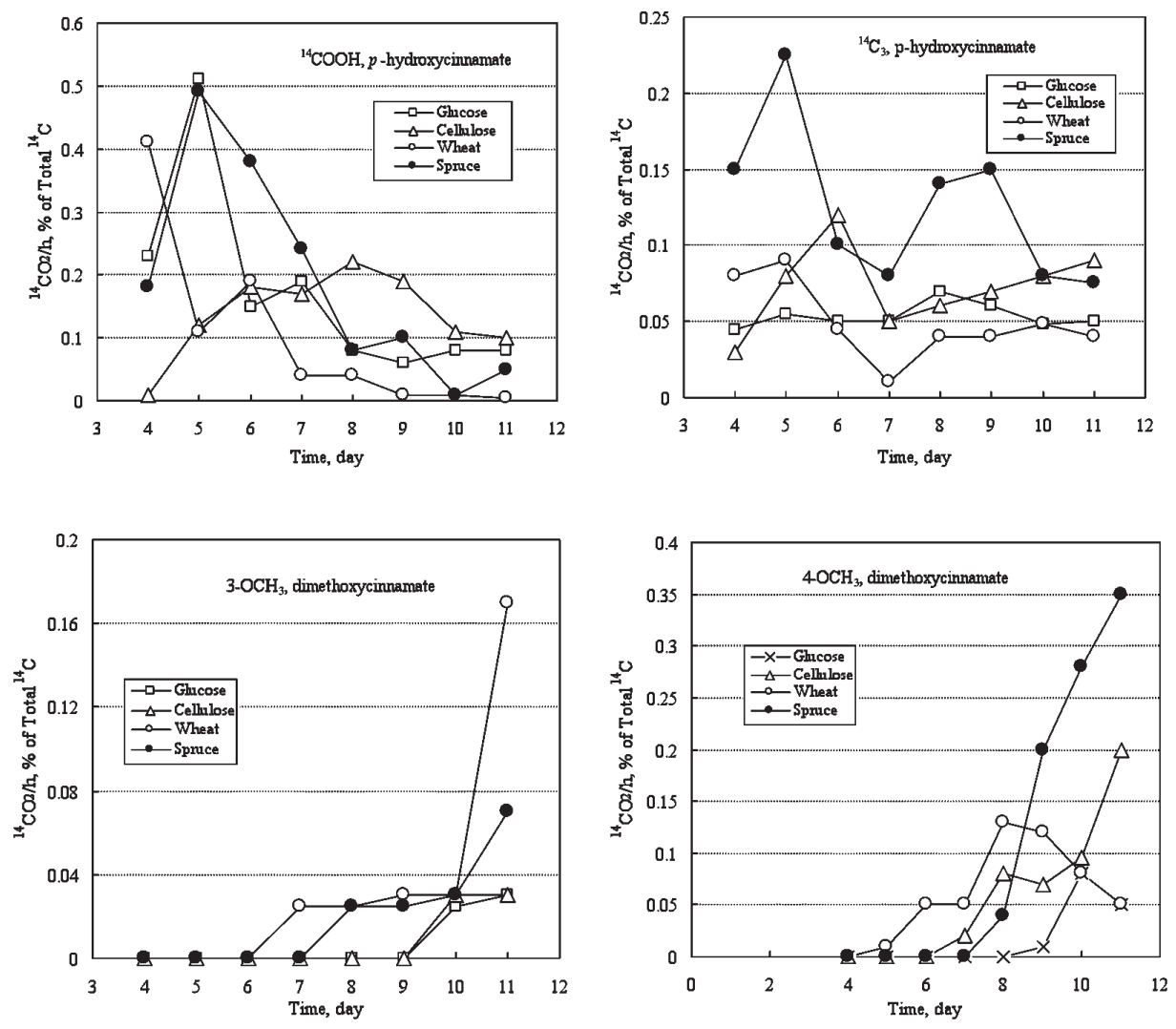

Fig. 1. ${ }^{14} \mathrm{CO}_{2}$ evolution from $\left({ }^{14} \mathrm{COOH}\right) p$-hydroxycinnamate $(\mathbf{A}) ;\left({ }^{14} \mathrm{C}_{3}\right) p$-hydroxyninnamate $(\mathbf{B})$; $\left[3-\mathrm{OCH}_{3}\right]$ dimethoxycinnamate $(\mathbf{C}) ;\left(4-\mathrm{OCH}_{3}\right)$ dimethoxycinnamate $(\mathbf{D})$ by Phlebia radiate grown in air aeration on $1 \%$ glucose $(\square-\square) ; 1 \%$ cellulose $(\triangle-\triangle) ; 1 \%$ wheat straw $(\bigcirc-\bigcirc)$ and $1 \%$ spruce wood ( 
decarboxylation seemed to occur in one step: all other patterns showed more or less periodical behaviour as in the degradation of veratric acid (Rogalski et al., 2000).

The release of carbon source from methoxyl groups does not occur directly but instead via methanol and formaldehyde formation (Frick and Crawford, 1983; Eriksson et al., 1990). In Phanerochaete chrysosporium three enzymes are probably involved in this pathway: (i) alcohol oxidase which transforms methanol to formaldehyde; (ii) formaldehyde dehydrogenase which transforms formaldehyde to formate; and (iii) formate dehydrogenase which oxidizes formate to carbon dioxide (Buswell, 1986; Eriksson and Nishida, 1989). Theoretically, the same transformation can be achieved by alcohol dehydrogenase but the enzyme isolated from the mycelium of Sporotrichum pulverulentum ( $P$. chrysosporium) has no activity towards methanol (Rudge and Bickerstaff, 1986).

The recovery of ${ }^{14} \mathrm{C}$-labeled elements coming from ${ }^{14} \mathrm{C}$ labeled aromatic acids isotopes is presented in Table 1. Such a high recovery of ${ }^{14} \mathrm{C}$ isotopes above $93 \%$ demonstrated that the used apparatus system was very tight. It can be observed from the above that about 30\% of carbon dioxide evolved from carboxyl-labeled cinnamate. The radioactivity in the mycelium was also above $10 \%$ in all cases and can be read as partially degraded or metabolized to the other components.

The degradation of cinnamate compounds in oxygen atmosphere were presented in (Fig. 2). As it was shown the mechanism of this component degradation was very similar to that in the case when the fungus grew in air atmosphere. The only difference is that the level of evolved radioactivities was double when the experiment was performed in oxygen.

The cellulose slightly repressed the decarboxylation of cinnamate in opposition to wheat straw and spruce wood, which doubled degradation. The maximum rate of decarboxylation was $c a$. $1.2 \%$ of the applied activity evolved as ${ }^{14} \mathrm{CO}_{2}$ per hour. The degradation of radiolabeled veratric acid (Rogalski et al., 2000), vanillic acid (Rogalski et al., 2003) and ferulic acid (Rogalski et al., 2003a) gave the same following sequence. At first the substrates after decarboxylation, and aliphatic chain cleavage were demethylated in the position 4 following the demethylation in the position 3 and finally aromatic ring cleavage was observed. The results from the Fusarium oxysporium indicated that after decarboxylation first in the position 3 and then in 4 occurred (Targoński et al., 1986). They also found that the presence of cellulose in culture medium decreases the rate of aromatic acid breakdown. In the case of $P$. radiata cellulose as a carbon source also decreased the rate of degradation except in the case of para-demethylation of veratric acid (Rogalski et al., 1996).

The HPLC data confirm the sequence of the methabolic steps presented above with isotopes. The hypothetical methabolic pathways were presented in Fig. 3. The transformation of cinnamic acids occurs via 3,4-dimethoxyvinylobenzene or 3-methoxy, 4-hydroxyvilylobenzene to vanillic acid, which is methabolized fur-

Table 1. Distribution of ${ }^{14} \mathrm{C}$-acitvities in 11-day-old Phlebia radiata cultures grown on various carbon sources in air conditions. The fungus was cultivated in the presence of ${ }^{14} \mathrm{C}$-labeled compounds and unlabeled cinnamic and coumaric acids ( $1 \mathrm{mM}$ )

\begin{tabular}{|c|c|c|c|c|c|}
\hline $\begin{array}{l}\text { Carbon } \\
\text { source }\end{array}$ & $\begin{array}{l}\text { Type of label } \\
\text { [1kBq/culture] }\end{array}$ & $\begin{array}{c}{ }^{14} \mathrm{CO}_{2} \\
\text { evolved } \\
{[\%]}\end{array}$ & $\begin{array}{c}{ }^{14} \mathrm{CO}_{2} \\
\text { mycelium } \\
{[\%]}\end{array}$ & $\begin{array}{c}{ }^{14} \mathrm{C} \text { in culture } \\
\text { filtrate } \\
{[\%]}\end{array}$ & $\begin{array}{c}\text { Total }{ }^{14} \mathrm{C} \\
{[\%]}\end{array}$ \\
\hline \multirow{4}{*}{$1 \%$ glucose } & $p-\mathrm{OH}\left[{ }^{14} \mathrm{COOH}\right]-\mathrm{cinn}^{\mathrm{a})}$ & $33.99 \pm 3.11$ & $9.96 \pm 0.42$ & $53.24 \pm 3.40$ & $97.10 \pm 5.11$ \\
\hline & $p-\mathrm{OH}\left[{ }^{14} \mathrm{C}_{3}\right]-\operatorname{cinn}$ & $12.16 \pm 1.92$ & $22.72 \pm 0.62$ & $63.72 \pm 1.90$ & $98.60 \pm 2.90$ \\
\hline & dimethoxy $\left[3-\mathrm{O}^{14} \mathrm{CH}_{3}\right]-\operatorname{cinn}$ & $0.98 \pm 0.10$ & $15.08 \pm 0.21$ & $83.34 \pm 2.10$ & $99.41 \pm 2.00$ \\
\hline & dimethoxy $\left[4-\mathrm{O}^{14} \mathrm{CH}_{3}\right]-\operatorname{cinn}$ & $4.46 \pm 0.51$ & $10.23 \pm 0.62$ & $84.11 \pm 3.22$ & $98.81 \pm 2.90$ \\
\hline \multirow{4}{*}{$1 \%$ cellulose } & $p-\mathrm{OH}\left[{ }^{14} \mathrm{COOH}\right]-\mathrm{cinn}$ & $28.55 \pm 1.63$ & $15.48 \pm 1.23$ & $52.87 \pm 1.72$ & $96.89 \pm 2.80$ \\
\hline & $p-\mathrm{OH}\left[{ }^{14} \mathrm{C}_{3}\right]-\operatorname{cinn}$ & $14.03 \pm 2.11$ & $23.83 \pm 0.96$ & $59.84 \pm 3.90$ & $97.72 \pm 4.14$ \\
\hline & dimethoxy $\left[3-\mathrm{O}^{14} \mathrm{CH}_{3}\right]-\operatorname{cinn}$ & $1.43 \pm 0.37$ & $32.54 \pm 1.62$ & $64.43 \pm 4.11$ & $98.40 \pm 3.14$ \\
\hline & dimethoxy $\left[4-\mathrm{O}^{14} \mathrm{CH}_{3}\right]-$ cinn & $13.51 \pm 1.67$ & $12.59 \pm 2.00$ & $70.80 \pm 2.80$ & $96.90 \pm 3.79$ \\
\hline \multirow{4}{*}{$1 \%$ wheat straw } & $p-\mathrm{OH}\left[{ }^{14} \mathrm{COOH}\right]-\operatorname{cinn}$ & $19.35 \pm 2.00$ & $12.60 \pm 0.93$ & $65.55 \pm 3.12$ & $97.52 \pm 4.33$ \\
\hline & $p-\mathrm{OH}\left[{ }^{14} \mathrm{C}_{3}\right]-\mathrm{cinn}$ & $9.17 \pm 0.99$ & $30.66 \pm 1.67$ & $54.87 \pm 2.70$ & $94.70 \pm 3.66$ \\
\hline & dimethoxy $\left[3-\mathrm{O}^{14} \mathrm{CH}_{3}\right]-\operatorname{cinn}$ & $5.30 \pm 0.76$ & $32.69 \pm 2.22$ & $58.61 \pm 4.31$ & $96.61 \pm 4.72$ \\
\hline & dimethoxy $\left[4-\mathrm{O}^{14} \mathrm{CH}_{3}\right]-\operatorname{cinn}$ & $11.54 \pm 1.33$ & $9.73 \pm 1.37$ & $76.63 \pm 2.20$ & $97.90 \pm 3.91$ \\
\hline \multirow{4}{*}{$1 \%$ spruce wood } & $p-\mathrm{OH}\left[{ }^{14} \mathrm{COOH}\right]-\mathrm{cinn}$ & $37.29 \pm 3.23$ & $14.65 \pm 2.17$ & $41.86 \pm 2.72$ & $93.81 \pm 5.40$ \\
\hline & $p-\mathrm{OH}\left[{ }^{14} \mathrm{C}_{3}\right]-\operatorname{cinn}$ & $24.59 \pm 3.00$ & $30.80 \pm 1.73$ & $39.21 \pm 3.20$ & $94.61 \pm 5.70$ \\
\hline & dimethoxy $\left[3-\mathrm{O}^{14} \mathrm{CH}_{3}\right]-\mathrm{cinn}$ & $2.27 \pm 0.83$ & $40.95 \pm 0.98$ & $53.68 \pm 2.10$ & $96.43 \pm 2.00$ \\
\hline & dimethoxy $\left[4-\mathrm{O}^{14} \mathrm{CH}_{3}\right]-$ cinn & $19.96 \pm 2.61$ & $21.47 \pm 1.63$ & $53.97 \pm 1.90$ & $95.43 \pm 3.71$ \\
\hline
\end{tabular}

a) cinn=cinnamic acid 

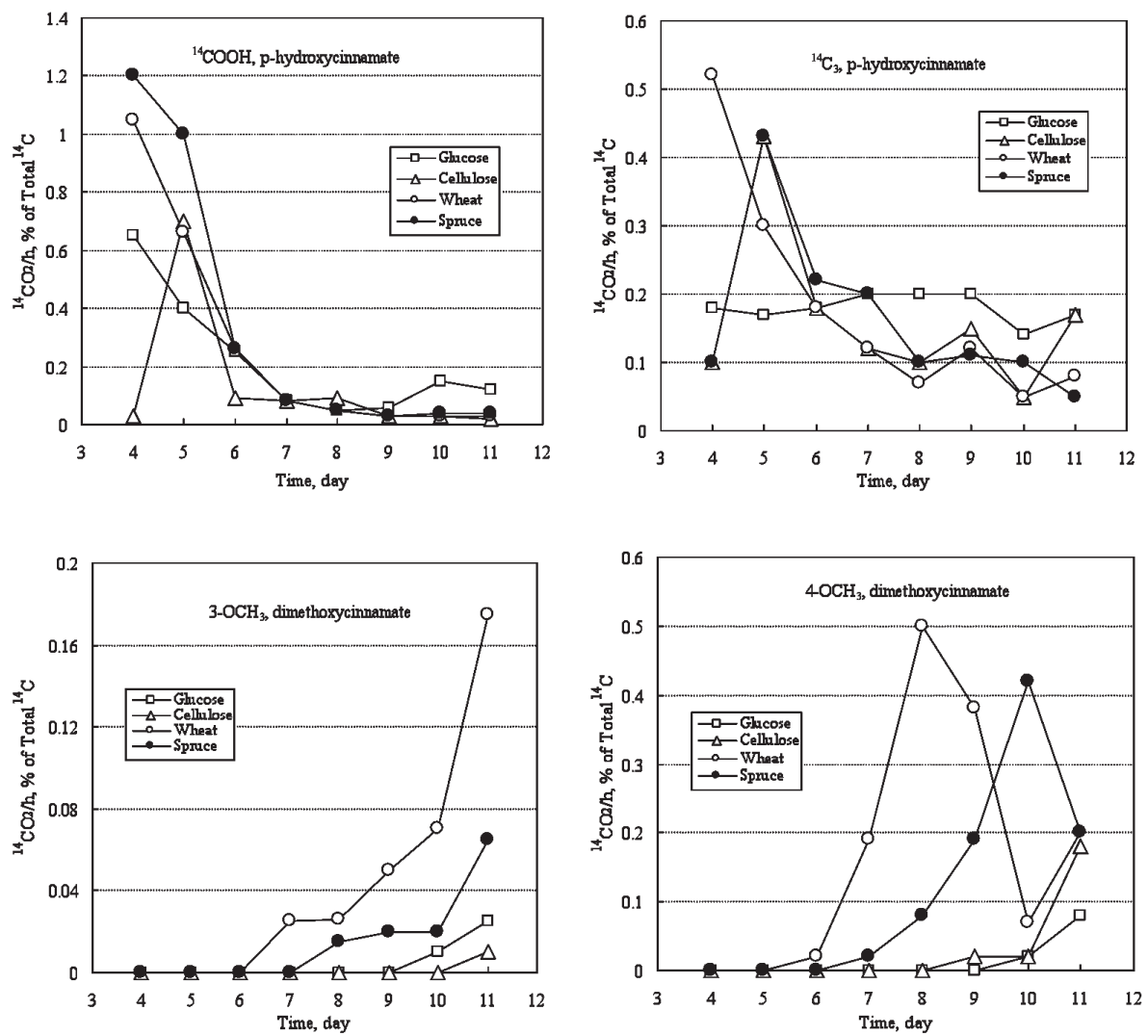

Fig. 2. ${ }^{14} \mathrm{CO}_{2}$ evolution from $\left[{ }^{14} \mathrm{COOH}\right) p$-hydroxycinnamate $(\mathbf{A}) ;\left[\left[{ }^{14} \mathrm{C}_{3}\right] p\right.$-hydroxycinnamate $(\mathbf{B}) ;\left[3-\mathrm{OCH}_{3}\right]$ dimethoxycinnamate $(\mathbf{C}) ;\left[4-\mathrm{OCH}_{3}\right]$ dimethoxycinnamate $(\mathbf{D})$ by Phlebia radiate grown in oxygen aeration on $1 \%$ glucose $(\square-\square) ; 1 \%$ cellulose $(\triangle-\triangle)$; $1 \%$ wheat straw $(\bigcirc-\bigcirc)$ and $1 \%$ spruce wood (-) as the sole carbon source.

Table 2. Distribution of ${ }^{14} \mathrm{C}$-acitvities in 10-day-old Phlebia radiata cultures grown on various carbon sources in oxygen conditions. The fungus was cultivated for 10 days in the presence of ${ }^{14} \mathrm{C}$-labelled compounds and unlabeled cinnamic and coumaric acids $(1 \mathrm{mM})$

\begin{tabular}{|c|c|c|c|c|c|}
\hline $\begin{array}{l}\text { Carbon } \\
\text { source }\end{array}$ & $\begin{array}{l}\text { Type of label } \\
\text { [1kBq/culture] }\end{array}$ & $\begin{array}{c}{ }^{14} \mathrm{CO}_{2} \\
\text { evolved } \\
{[\%]}\end{array}$ & $\begin{array}{c}{ }^{14} \mathrm{CO}_{2} \\
\text { mycelium } \\
{[\%]}\end{array}$ & $\begin{array}{c}{ }^{14} \mathrm{C} \text { in culture } \\
\text { filtrate } \\
{[\%]}\end{array}$ & $\begin{array}{c}\text { Total }{ }^{14} \mathrm{C} \\
{[\%]}\end{array}$ \\
\hline \multirow{4}{*}{$1 \%$ glucose } & $p-\mathrm{OH}\left[{ }^{14} \mathrm{COOH}\right]-\mathrm{cinn}^{\mathrm{a})}$ & $38.39 \pm 4.21$ & $3.79 \pm 0.41$ & $56.32 \pm 2.21$ & $98.00 \pm 5.41$ \\
\hline & $p-\mathrm{OH}\left[{ }^{14} \mathrm{C}_{3}\right]-\operatorname{cinn}$ & $34.12 \pm 2.94$ & $9.61 \pm 0.41$ & $53.37 \pm 3.20$ & $97.11 \pm 5.10$ \\
\hline & dimethoxy $\left[3-\mathrm{O}^{14} \mathrm{CH}_{3}\right]-$ cinn & $0.39 \pm 0.09$ & $8.29 \pm 0.52$ & $90.72 \pm 1.58$ & $99.40 \pm 1.88$ \\
\hline & dimethoxy $\left[4-\mathrm{O}^{14} \mathrm{CH}_{3}\right]-$ cinn & $2.47 \pm 0.55$ & $6.27 \pm 0.37$ & $90.16 \pm 1.70$ & $98.90 \pm 2.00$ \\
\hline \multirow{4}{*}{$1 \%$ cellulose } & $p-\mathrm{OH}\left[{ }^{14} \mathrm{COOH}\right]-\operatorname{cinn}$ & $28.76 \pm 1.99$ & $7.00 \pm 0.41$ & $61.84 \pm 2.41$ & $97.60 \pm 3.65$ \\
\hline & $p-\mathrm{OH}\left[{ }^{14} \mathrm{C}_{3}\right]-$ cinn & $29.22 \pm 2.11$ & $6.97 \pm 0.33$ & $58.51 \pm 2.90$ & $94.70 \pm 4.21$ \\
\hline & dimethoxy $\left[3-\mathrm{O}^{14} \mathrm{CH}_{3}\right]-$ cinn & $0.16 \pm 0.06$ & $16.49 \pm 0.52$ & $76.65 \pm 2.11$ & $93.30 \pm 2.33$ \\
\hline & dimethoxy $\left[4-\mathrm{O}^{14} \mathrm{CH}_{3}\right]-$ cinn & $5.66 \pm 1.14$ & $13.97 \pm 0.41$ & $75.77 \pm 1.90$ & $95.40 \pm 2.10$ \\
\hline \multirow{4}{*}{$1 \%$ wheat straw } & $p-\mathrm{OH}\left[{ }^{14} \mathrm{COOH}\right]-\operatorname{cinn}$ & $48.52 \pm 2.75$ & $7.50 \pm 0.40$ & $40.88 \pm 1.41$ & $96.91 \pm 3.11$ \\
\hline & $p-\mathrm{OH}\left[{ }^{14} \mathrm{C}_{3}\right]-\operatorname{cinn}$ & $34.20 \pm 2.40$ & $13.55 \pm 0.45$ & $49.95 \pm 1.90$ & $97.72 \pm 3.00$ \\
\hline & dimethoxy $\left[3-\mathrm{O}^{14} \mathrm{CH}_{3}\right]-$ cinn & $8.01 \pm 1.00$ & $14.63 \pm 0.50$ & $76.66 \pm 2.22$ & $99.31 \pm 2.00$ \\
\hline & dimethoxy $\left[4-\mathrm{O}^{14} \mathrm{CH}_{3}\right]-\operatorname{cinn}$ & $32.58 \pm 1.60$ & $11.48 \pm 0.31$ & $53.74 \pm 1.60$ & $97.80 \pm 2.62$ \\
\hline \multirow{4}{*}{$1 \%$ spruce wood } & $p-\mathrm{OH}\left[{ }^{14} \mathrm{COOH}\right]-\operatorname{cinn}$ & $61.55 \pm 1.72$ & $5.73 \pm 0.40$ & $30.82 \pm 1.20$ & $98.10 \pm 1.99$ \\
\hline & $p-\mathrm{OH}\left[{ }^{14} \mathrm{C}_{3}\right]-\mathrm{cinn}$ & $48.78 \pm 1.22$ & $14.85 \pm 0.51$ & $33.07 \pm 1.83$ & $96.71 \pm 2.88$ \\
\hline & dimethoxy $\left[3-\mathrm{O}^{14} \mathrm{CH}_{3}\right]-$ cinn & $2.45 \pm 0.20$ & $20.89 \pm 0.46$ & $75.86 \pm 2.20$ & $99.21 \pm 2.00$ \\
\hline & dimethoxy $\left[4-\mathrm{O}^{14} \mathrm{CH}_{3}\right]-$ cinn & $21.95 \pm 2.64$ & $16.41 \pm 0.60$ & $60.14 \pm 2.11$ & $98.50 \pm 3.40$ \\
\hline
\end{tabular}

\footnotetext{
a) $\operatorname{cinn}=$ cinnamic acid
} 


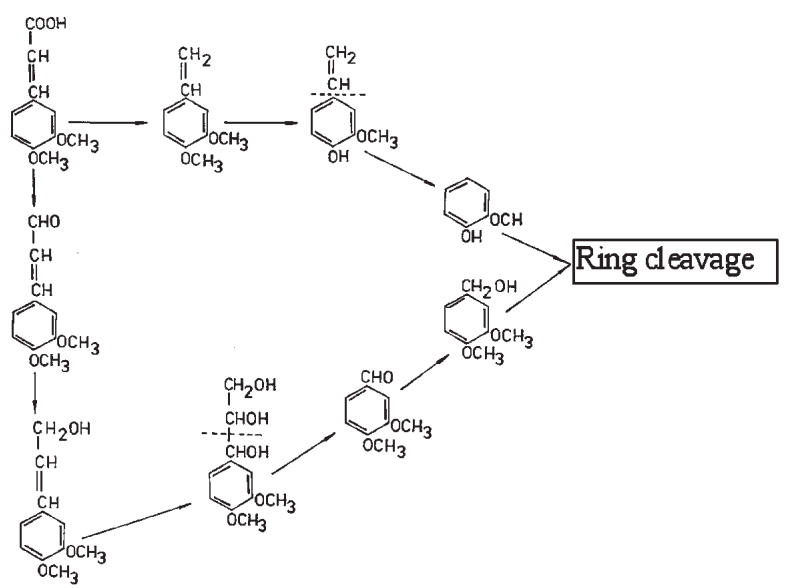

Fig. 3. Pathways for cinnamic acid metabolism by Phlebia radiate.

ther as described earlier (Rogalski et al., 2003). In the case of Lentinus edodes the degradation of 3,4-dimethoxycinnamate results in ferulic acid or 3,4 dimethoxycinnamic aldehyde (Crestini and Sermanni, 1994). Trametes versicolor growing on the media with low nitrogen and high oxygen oxidized 3,4-dimethoxycinnamic alcohol to veratrylglycerol; the cleavage between $\mathrm{C}_{\alpha}$ and $\mathrm{C}_{\exists}$ was next observed giving veratraldehyde and veratryl alcohol (Kamaya and Higuchi, 1984). The peroxidase from Nicotina tabacum can rapidly oxidize sinapic acid to 4-coumaric acid, ferulic acid and coniferyl alcohol (Takahama et al., 1996). Fungal laccase from Pycnoporus oryzae oxidized sinapic acid to ferulic- and $p$-coumaric acid (Takahama, 1995), whereas laccase from Trametes versicolor transform sinapic acid to dimmers by the reaction of coupling of two phenoxy radilals and latter to 2,6 dimethoxy- $p$-benzoquinone (Lacki and Duvnjak, 1998).

\section{REFERENCES}

Bache, R. and N. Pfennig 1981 Selective isolation of Acetobacterium woodii on methoxylated aromatic acids and determination of growth yields, Arch. Microbiol., 130: 255-261

Bellamy, W. D. 1974 Single cell proteins from cellulosic wastes, Biotech. Bioeng., 16: 869-880

Bourbonnais, R. and M. g. Paice 1992 Demethylation and delignification of kraft pulp by Trametes versicolor laccase presence of 2,2'-azinobis-(3-ethylbenzthiazoline-6-sulphonate), Appl. Microbiol. Biotechnol., 36: 823-827

Bourbonnais, R., M. G. Paice, I. D. Reid, P. Lanthier and M. Yaguchi 1995 Lignin oxidation by laccase isozymes from Trametes versicolor and role of the mediator 2,2'-azinobis (3-ethylbenzthiazoline-6-sulfonate) in kraft lignin depolymerization, Appl. Environ. Microbiol., 61: 1876-1880

Buswell, J. A. 1986 Methanol formation in Phanerochaete chrysosporium, Proc. $3^{\text {rd }}$ Intern. Conf. Biotechnol. Pulp and Paper Ind. (P. Ander ed.), Stockholm, Sweden, pp. 20-23

Buswell, J. A., P. Ander, B. Pettersson and K.-E. Eriksson 1979 Oxidative decarboxylation of vanillic acid by Sporotrichum pulverulentum, FEBS Lett., 103: 98-101

Call, H. P. 1994 Process for modifying, breaking down or bleaching lignin, materials containing lignin or like substances: PCT Pat. Appl.: WO94/29510

Call, H. P. and L. Mucke 1997 History, overview and application of mediated lignolytic systems, especially laccase-mediatorsystem (Lignozym R-process), J. Biotechnol., 53: 163-202

Chesson, A., C. S. Steward and R. J. Wallace 1982 Influence of plant phenolic acids on growth and cellulytic activity of rumen bacteria, Appl. Environ. Microbiol., 44: 597-603

Crawford, R. L. and P. P. Olson 1978 Microbial catabolism of vanillate: decarboxylation to guaiacol, Appl. Environ. Microbiol., 36: 539-543

Crestini, C. and G. G. Sermanni 1994 Oxidation and aromatic ring cleavage of 4-methoxy and 3,4-dimethoxycinnamic acid by Lentinus edodes, Biotechnol. Lett., 16: 995-1000

Eggert, C., U. Temp and K.-E. Eriksson 1997 Laccase is essential for lignin degradation by the white-rot fungus Pycnoporus cinnabarinus, FEBS Lett., 407: 89-92

Eggert, C., U. Temp, J. F. Dean and K.-E. Eriksson 1996 A fungal metabolite mediates degradation of non-phenolic lignin structures and synthetic lignin by laccase, FEBS Lett., $\mathbf{3 9 1}$ : $144-148$

Eriksson, K.-E., R. A. Blanchette and P. Ander 1990 Microbial and enzymatic degradation of wood and wood components ( $\mathrm{T}$. E. Timell ed.), Springer-Verlag, Berlin, pp. 1-399

Eriksson, K.-E. and A. Nishida 1989 Methanol oxidase of Phanerochaete chrysosporium, Meth. Enzymol., $\mathbf{1 6 1}$ 322-326

Evans, C. S., M. V. Dutton, F. Guillen and R. G. Veness 1994 Enzymes and small molecular mass agents involved with lignocellulose degradation, FEMS Microbiol. Rev., 13: 235-240

Evans, C. S., I. M. Gallagher, P. T. Atkey and D. A. Wood 1991 Location of degradative enzymes in white-rot decay of lignocellulose, Biodegradation, 2: 93-106

Fengel, D. 1971 Ultrastructural organization of the cell wall components, J. Polym. Sci. C, 36: 383-392

Flournoy, D. S., T. K. Kirk and T. L. Highley 1991 Wood decay by brown-rot fungi: changes in pore structure and cell wall volume, Holzforschung, 45: 383-388

Freudenberg, K. 1965 Lignin: its constitution and formation from p-hydroxycinamyl alcohols, Science, 148: 595-600

Frick, T. D. and R. L. Crawford 1983 Mechanism of microbial demethylation of lignin model polymers, In: Recent advances in lignin biodegradation research (T. Higuchi, H.-m. Chang, T. K. Kirk eds.), UNI Publ. Co., Tokyo, pp. 143-152

Galkin, S., T. Vares, M. Kalsi and A. Hatakka 1998 Production of organic acids by different white-rot fungi as detected using capillary zone electrophoresis, Biotechnol Techniques, 12: $267-271$

Goodell, B., J. Liu, L. J. Jellison, A. Paszczynski and F. Fekete 1996 Chelation activity and hydroxyl radical production mediated by low molecular weight phenolate compounds isolated from Gloeophyllum trabeum. In: Messner, K. and Srebotnik, E. (eds.): Biotechnology in the Pulp and Paper Industry, Recent Advances in Applied and Fundamental Research. Vienna, Austria: Facultas-Universitatsverlag, pp. 591-594

Grbic-Galic, D. 1985 Fermentative and oxidative transformation of ferulate by a facultatively anaerobic bacterium isolated from sewage sludge, Appl. Environ. Microbiol., 130: 255-261

Gurujeyalakshni, G. and M. Mahadevan 1987 Degradation of ferulic acid by Bacillus subtillus, Curr. Microbiol., 16: 69-73

Hatakka, A. and A. Uusi-Rauva 1983 Degradation of ${ }^{14} \mathrm{C}-$ labelled poplar wood lignin by selected white-rot fungi, Eur J Appl Microbiol Biotechnol., 17: 235-242

Hofrichter, M., T. Vares, M. Kalsi, S. Galkin, K. Scheibner, W. Fritsche and A. Hatakka 1999 Production of manganese peroxidase and organic acids and mineralization of ${ }^{14} \mathrm{C}$-labelled lignin $\left({ }^{14} \mathrm{C}-\mathrm{DHP}\right)$ during solid-state fermentation of wheat straw with the white rot fungus Nematoloma frowardii, Appl. Environ. Microbiol., 65: 1864-1870

Huang, Z., L. Dostal and J. P. M. Rosazza 1993 Mechanisms of ferulic acid conversions to vanillic acid and guaiacol by Rhodotorula rubra, J. Biol. Chem., 268: 23954-23958

Jurkova, M. and M. Wurst 1993 Biodegradation of aromatic carboxylic acid by Pseudomonas mira, FEMS Microbiol. Lett., 
111: $245-250$

Kamaya, Y. and T. Higuchi 1984 Metabolizm of 3,4-dimethoxycinnamyl alkohol and derivatives by Coriolus versicolor, FEMS Microbiol. Lett., 24: 225-229

Lacki, K. and Z. Duvnjak 1998 Transformation of 3,5-dimethoxy, 4-hydroxycinnamic amid by polyphenol oxidase from the fungus Trametes versicolor: product elucidation studies, Biotechnol. Bioeng., 57: 694-703

Leonowicz, A., Nam-Seok Cho, M. Wojta-Wasilewska, J. Rogalski and J. Luterek 1997 Enzymes of white-rot fungi cooperate in biodeterioration of lignin barrier, J. Kor. Wood Sci. Technol., 25: 1-20

Leonowicz, A., A. Matuszewska, J. Luterek, D. Ziegenhagen, M. Wojtas-Wasilewska, Nam-Seok Cho, M. Hofrichter and J. Rogalski 1999 Biodegradation of lignin by white-rot fungi, Fung. Genet. Biol., 27: 175-185

Leonowicz, A., M. Wojtas-Wasilewska, J. Rogalski and J. Luterek 1987 Biological decomposition of ligninocellulose. In: Progress in Biotechnology 4, (A. Blazej and J. Zemek eds.), Elsevier, Amsterdam, Oxford, New York, Tokyo, pp. 415-451

Lewis, N. G. and E. Yamamoto 1990 Lignin: Occurance, biogenesis and biodegradation, Ann. Rev. Plant Physiol. Plant Mol. Biol., 41: 455-496

Longa, B. 1996 Investigation on cellulolytic enzymes from Phlebia radiata, Ph. D. Thesis, Maria Curie-Sklodowska University, Lublin, pp. 1-178

Lundell, T., A. Leonowicz, J. Rogalski and A. Hatakka 1990 Formation and action of lignin-modifying enzymes in cultures of Phlebia radiata supplemented with veratric acid, Appl. Environ. Microbiol., 56: 2623-2629

Lundquist, K. and T. K. Kirk 1978 De novo synthesis and decomposition of veratryl alcohol by a lignin-degrading basidiomycete, Phytochemistry, 17: 1676-1680

Majcherczyk, A., C. Johannes and A. Huttermann 1999 Oxidation of aromatic alcohols by laccase from Trametes versicolor mediated by the 2,2'-azino-bis-(3-ethylbenzothiazoline-6sulphonic acid) cation radical and dication, Appl. Microbiol. Biotechnol., 51: 267-276

Monties, B. 1989 Lignins - In: Methods in Plant Biochemistry, (J. B. Harborne, ed.), Academic Press, London, pp. 113-157

Rogalski, J. and Nam-Seok Cho 2003 Degradation of vanillic amid by white rot fungus Phlebia radiata, Proc. $4^{\text {th }}$ Internat. Sym. For. Prod. Biosci., Chungbuk Nat. Univ., Cheongju, Korea, pp. 271-277

Rogalski, J. and Nam-Seok Cho 2003a Degradation of ferulic amid by white rot fungus Phlebia radiata, Proc. $4^{\text {th }}$ Internat. Sym. For. Prod. Biosci., Chungbuk Nat. Univ., Cheongju, Korea, pp. 254-262

Rogalski, J., A. Hatakka and A. Leonowicz 2000 Demethylation of $\left[{ }^{14} \mathrm{C}\right]$-labelled veratric amid and oxidation of metanol and formaldehyde by the white rot fungus Phlebia radiata, Acta Microbiol. Polon., 49: 207-216

Rogalski, J., T. Lundell, A. Leonowicz and A. Hatakka 1991 Influence of aromatic compounds and lignin on production of ligninolytic enzymes by Phlebia radiata, Phytochemistry, 30: 2869-2872

Rogalski, J., T. Lundell, A. Leonowicz and A. Hatakka 1992 Influence of lignin-related aromatic compounds on the production of ligninolytic enzymes by Phlebia radiata. In Ligninocellulosics: science, technology, development and use (J. F. Kennedy, G. O. Phippips and P. A. Williams eds.), Ellis Horwood Ltd., New York, pp. 55-60

Rogalski, J., O. Niemenmaa, A. Uusi-Rauva and A. Hatakka 1996 De novo synthesis of aromatic compounds and metabolism of ${ }^{14} \mathrm{C}$-glucose in the presence and absence of phenolic compounds by Phlebia radiata. In: $6^{\text {th }}$ Intern. Conf. Biotechnol. Pulp Paper Ind., (E. Srebotnik and K. Messner eds.), FacultasUniversitatverlag, Vienna, Austria, pp. 451-454

Rogalski, J. 1992 Biotransformation of ligninocellulose by whiterot fungi for example of Phlebia radiata., Habilitation thesis, Maria Curie-Sklodowska University, Lublin, pp. 1-196

Rudge, J. and G. F. Bickerstaff 1986 Purification and properties of an alcohol dehydrogenase from Sporotrichum pulverulentum, Enzyme Microbiol. Technol., 8: 120-124

Schimada, M., A. Ohta, H. Kurosaki, T. Hattori, T. Higuchi and M. Takahashi 1989 In: Plant cell wall polymers: biogenesis and biodegradation, N. G. Lewis and M. G. Paice (eds.), ACS Symp. Ser. No. 399, American Chemical Society, Washington, pp. 412-425

Shimada, M., F. Nakatsubo, T. Higuchi and T. K. Kirk 1981 Biosynthesis of the secondary metabolite veratryl alcohol in relation to lignin degradation by Phanerochaete chrysosporium, Arch. Microbiol., 129: 321-324

Shimazono, H., H. H. Nishimura and S. Kawachi 1978 Transformations of aromatic acids by wood destroying fungi. II Transformations of various aromatic acids by Polystictus versicolor, Bull. Fac. Agr. Miyazaki University, 25: 369-376

Takahama, U. 1995 Oxidation of hydroxycinnamic acid and hydroxycinnamyl alcohol derivatives by laccase and peroxidase. Interactions among p-hydroxyphenyl, guaiacyl and syringyl groups during the oxidation reactions, Physiol. Plantarum, 93: 61-68

Takahama, U., T. Oniki and H. Shimokawa 1996 A possible mechanism for the oxidation of sinapyl alkohol by peroxidasedependent reactions In the apoplast: enhancement of the oxidation by hydroxycinnamic acid and components of the apoplast, Plant. Cell Physiol., 37: 499-504

Takao, S. 1965 Organic acid production by basidiomycetes: I. Screening of acid-production strains, Appl. Microbiol., 13 $732-737$

Targoński, Z., J. Rogalski and J. Szczodrak 1986 Decomposition of ${ }^{14} \mathrm{C}$-labelled vanillic acid and its related compounds by Fusarium oxysporium, System. Appl. Microbiol., 8: 148-151

Toms, A. and J. M. Wood 1970 The degradation of trans-ferulic acid by Pseudomonas acidovorans, Biochemistry, $\mathbf{9}$ 337-343 